\title{
KEARIFAN LOKAL DALAM INOVASI PEMBELAJARAN BIOLOGI: STRATEGI MEMBANGUN ANAK INDONESIA YANG LITERATE DAN BERKARAKTER UNTUK KONSERVASI ALAM
}

\author{
Siti Alimah \\ Jurusan Biologi FMIPA Universitas Negeri Semarang \\ siti_alimah@mail.unnes.ac.id
}

\begin{abstract}
ABSTRAK
Tujuan dari artikel ini adalah mengkaji dan menganalisis kearifan lokal sebagai sumber belajar biologi. Sumber Belajar biologi merupakan segala sesuatu yang bersumber dari alam dan lingkungan sekitar siswa yang dapat memudahkan mereka belajar. Sumber belajar biologi dapat didesain oleh guru sebagai bentuk inovasi pembelajaran sesuai dengan pemikiran kritis, kreatif, dan inovatif untuk efektifitas pembelajaran biologi. Efektifitas pembelajaran biologi dapat tercapai jika guru mampu memberi kemudahan belajar untuk siswa baik di kelas maupun di luar kelas. Ide/gagasan kearifan lokal merupakan salah satu bentuk lingkungan belajar yang dapat diinovasi guru sebagai sumber belajar. Inovasi sumber belajar tersebut dapat dimanifestasikan dalam bentuk POBATEL, yakni Pesan, Orang, Bahan, Alat, Teknik, dan Lingkungan. Parijoto, Gusjigang, Lembur, Nyadran, dan Mantenan merupakan contoh beberapa kearifan lokal yang dapat dimanfaatkan sebagai sumber belajar. Metodologi digunakan untuk mewujudkan sumber belajar dalam bentuk POBATEL adalah model penelitian reseach and development. Bentuk produk yang dihasilkan berupa bahan ajar, media pembelajaran, metode, dan model pembelajaran biologi. Ragam sumber belajar tersebut jika dimanfaatkan sesuai dengan karakteristik siswa dan materi pembelajaran dan cara pembelajaran yang benar mampu menggali potensi kemampuan berpikir analitik siswa untuk dapat secara kritis dan kreatif melakukan pemecahan masalah. Jika hal tesebut dibiasakan di setiap pembelajaran biologi mereka, maka anak yang literate dan berkarakter mampu dihasilkan dalam pembelajaran tersebut.
\end{abstract}

Kata Kunci: Kearifan Lokal, Inovasi Pembelajaran Biologi, Sumber Belajar

\section{PENDAHULUAN}

Indonesia merupakan negara kepulauan yang kaya dengan budaya dan sumber daya alam hayati lokal. Kekayaan budaya dan sumber daya alam hayati lokal mampu memberikan ciri khas atau tradisi pada masing-masing pulau hingga mewujudkan kekayaan tradisonal. Kekayaan tradisional mencerminkan kebudayaan tradisonal yang menjadi ciri khas atau identitas budaya dari suatu daerah tertentu. Kebudayaan merupakan buah pikir/ide/gagasan yang berasal dari masyarakat setempat yang dihasilkan untuk berinteraksi secara arif dengan lingkungannya. Kebudayaan tersebut diturunkan dari generasi ke generasi secara turun temurun dalam kurun waktu lama dengan niat baik untuk melestarikannya serta menjaga tatanan kehidupan bermasyarakat. Dengan demikian kebudayaan tradisional dapat dimaknai sebagai kearifan lokal.

Kearifan lokal, menurut Kamus Besar Bahasa Indonesia berasal dari dua kata, yakni kearifan dan lokal. Kearifan dapat diartikan sebagai kebijaksanaan, sedangkan lokal atau tradisional dapat diartikan sebagai ruang yang terbatas pada satu tempat tertentu atau setempat. Dengan demikian, berdasarkan asal penyusun katanya kearifan lokal dapat diartikan sebagai kebijaksanaan setempat yang bersifat terbatas/tertentu untuk suatu kejadian, peristiwa, produksi, tumbuh, hidup dan sebagainya. Kearifan lokal dalam bahasa asing dikonsepsikan sebagai local wisdom (kebijaksanaan setempat), local genius (kecerdasan setempat), dan local knowledge (pengetahuan setempat). 
Local Wisdom, dalam Kamus Inggris Indonesia John M. Echols dan Hassan Syadily menyatakan bahwa local berarti setempat, sedangkan wisdom (kearifan) sama dengan kebijaksanaan sehingga dapat dikatakan bahwa local wisdom (kearifan setempat) yang dapat dimaknai sebagai gagasan-gagasan setempat (local) yang bersifat bijaksana, penuh kearifan, bernilai baik, yang tertanam dan diikuti oleh anggota masyarakatnya (Sartini, 2004). Kearifan lokal adalah kebenaran yang telah mentradisi atau ajeg dalam suatu daerah tertentu. Kearifan lokal memiliki kandungan nilai kehidupan yang tinggi dan layak terus digali, dikembangkan, dijaga dan dilestarikan. Kearifan lokal merupakan produk budaya masa lalu yang runtut secara terus-menerus dan dapat dijadikan sebagai pegangan hidup masyarakat setempat. Kearifan lokal meskipun bernilai dan bersifat lokal namun nilai yang terkandung didalamnya dapat bersifat sangat universal.

Kearifan lokal dapat dikonsepsikan sebagai Local Genius. Lokal Genius merupakan sejumlah karakteristik budaya daerah yang dimiliki sebagaian besar masyarakat setempat sebagai akibat dari pengalaman mereka di masa lalu. Local genius disebut juga sebagai cultural identity, yakni identitas/kepribadian budaya bangsa yang menyebabkan bangsa tersebut mampu menyerap dan mengolah kebudayaan asing sesuai watak dan kemampuan sendiri (Ayatrohaedi, 1986). Unsur budaya daerah berpotensi sebagai local genius, karena unsur budaya daerah telah teruji kemampuannya untuk bertahan sampai sekarang. Local genius memiliki cir-ciri: (1) mampu bertahan terhadap dunia luar; (2) memiliki kemampuan mengakomodasi unsur-unsut budaya luar; (3) mempunyai kemampuan mengintegrasikan unsur budaya luar ke dalam budaya asli; (4) mempunyai kemampuan mengendalikan; dan (5) mampu memberikan arah pada perkembangan budaya.

Kearifan lokal, selain dapat dikonsepsikan sebagai local genius, dapat juga dikonsepsikan sebagai local knowledge karena kearifan lokal berakar dari sistem pengetahuan. Kearifan lokal yang dikonsepsikan sebagai local knowledge dimaknai sebagai pengetahuan lokal. Pengetahuan lokal merupakan pengetahuan khas yang dimiliki suatu masyarakat atau budaya tertentu yang telah berkembang lama sebagai hasil dari hubungan timbal balik antara masyarakat dan lingkungannya. Local knowledge merupakan buah pikir/gagasan masyarakat setempat yang bernilai baik. Bentuk-bentuk kearifan lokal dapat berupa pandangan hidup, nilai, norma, etika, kepercayaan, hukum adat, adat istiadat, dan aturan-aturan khusus yang biasanya tersimbolosasi dalam mitos dan ritual (Sartini, 2004).

Ragam bentuk-bentuk kearifan lokal yang beraneka ragam memberikan fungsi yang berbeda-beda. Fungsi tersebut antara lain: (1) konservasi nilai dan pelestarian sumber daya alam; (2) mengembangkan sumber daya manusia; (3) mengembangan kebudayaan dan ilmu pengetahuan alam; (3) sebagai petuah, kepercayaan, sastra, dan pantangan. Selain fungsi yang berbeda, ragam bentuk kearifan lokal juga memiliki makna yang berbeda-beda. Makna tersebut antara lain sosial, etika dan moral. Berdasarkan fungsi dan makna tersebut, maka ranah kearifan lokal berkembang mulai dari yang bersifat teologis, pragmatis, sampai dengan teknik.

Menilik pada kearifan lokal yang bersifat pragmatis, maka kearifan lokal memiliki nilai kebermanfaatan untuk dapat dijadikan sebagai sumber belajar biologi. Kearifan lokal dapat digunakan sebagai dasar pengetahuan untuk melakukan inovasi dalam pembelajaran biologi di sekolah. Kearifan lokal dapat dimanfaatkan sebagai sumber belajar biologi karena membawa fungsi konservasi nilai dan pelestarian sumber daya alam yang wajib diketahui, 
dipahami, dan dilestarikan oleh generasi bangsa melalui pendidikan, khususnya pembelajaran di sekolah oleh guru. Kearifan lokal dapat dimanfaatkan sebagai sumber belajar biologi dengan cara melakukan analisis terhadap kearifan lokal untuk memahami karakteritiknya guna disesuaikan dengan tujuan pembelajaran pada konsep biologi tertentu. Misalkan Kearifan lokal Kota semarang yang disebut sebagai Mantenan.

Kearifan lokal mantenan di Kota Semarang merupakan tradisi upacara pernikahan dengan segenap ubo rampe yang menyertainya. Ubo rampe upacara tersebut antara lain cengkir gadhing, godhong opo-opo, godhong alang-alang, godhong kluweh, pari, janur, pisang raja, pandan, kembang setaman, dan beras kuning dapat dimanfaatkan siswa untuk belajar tentang plantae dan keanekaragaman hayati. Saat mereka belajar plantae dan keanekaragaman hayati dengan sarana dan media kearifan lokal matenan tersebut, perlu ditekankan untuk menjaga kelestarian sumber daya hayati yang terdapat dalam ubo rampe tradisi mantenan dengan cara yang paling sederhana adalah satu siswa menaman satu jenis spesies tersebut di lingkungan sekolah atau di lingkungan sekitar mereka tinggal. Dengan demikian, pada pembelajaran tersebut ada unsur inisiasi untuk kegiatan konservasi biologi.

Kearifan lokal mantenan dapat dimanfaatkan dalam pembelajaran biologi untuk mendukung fungsi konservasi nilai dan pelestarian sumber daya alam melalui pembelajaran biologi di sekolah. Guru biologi dapat memfasilitasi kegiatan pembelajaran dengan mengintegrasikan kearifan lokal tradisi mantenan dalam belajar siswanya. Kearifan lokal yang diintegrasikan dalam kegiatan pembelajaran siswa melalui tangan kreatif dari guru biologi mampu membawa anak menjadi literate, yakni siswa tidak sekedar paham materi biologi, namun mereka memanfaatkan pengetahuan yang mereka ketahui dan pahami memecahkan permasalahan dalam kehidupan sehari-hari yang bersumber dari kearifan lokal. Untuk dapat membangun siswa yang literate, guru perlu menggali potensi berpikir untuk kemudian melatih dan membiasakannya dalam kegiatan pembelajaran dengan pemecahan masalah (problem solving) berbasis pada kearifan lokal.

Pembelajaran biologi yang diintegrasikan dengan kearifan lokal, mampu menggali potensi berpikir, melatih dan membiasakannya untuk melakukan kegiatan pemecahan masalah yang bersumber dari kearifan lokal. Pembelajaran biologi dengan kegiatan pemecahan masalah bersumber pada kearifan lokan mampu mengaktifkan struktur kognitif siswa untuk secara kritis melakukan analisis permasalahan yang terjadi di lingkungan sekitar mereka dan secara kreatif mencari solusi permasalahannya berdasarkan pada nilai-nilai yang terkadung dalam kearifan lokal yang digunakan sebagai sumber belajar. Dengan demikian kemampuan berpikir kritis dan kreatif dapat dibiasakan melalui pembelajaran biologi dengan kegiatan pemecahan masalah dengan bersumber pada kearifan lokal.

Bersumber dari paparan paragraf sebelumnya, maka tujuan artikel ini adalah untuk menganalisis kearifan lokal sebagai bentuk inovasi sumber belajar biologi untuk membangun siswa litarate dan berkarakter sekaligus sebagai agen konservasi nilai dan pelestarian sumber daya alam, dan mengkaji metodologi yang dapat digunakan untuk menghasilkan produk inovasi sumber belajar biologi berbasis kearifan lokal melalui kegiatan penelitian dan pengembangan. 


\section{METODE PENELITIAN}

Jenis penelitian kualitatif ini menggunakan metode kajian pustaka dari beberapa sumber referensi terkait kearifan lokal sebagai sumber belajar biologi.

\section{PEMBAHASAN}

Obyek pembelajaran biologi adalah alam dan lingkungan sekitarnya baik yang bersifat fisik, sosial budaya dan teknologi. Pengetahuan dan ilmu tentang hidup dan kehidupan dipelajari siswa di sekolah berorientasi pada metode ilmiah. Langkah-langkah pembelajaran yang berpedoman pada langkah-langkah metode ilmiah mengandung nilai dan sikap ilmiah. Observasi merupakan langkah utama dalam melakukan serangkaian langkah-langkah pembelajaran dengan metode ilmiah. Observasi dapat dilakukan melalui kegiatan pengamatan fakta-fakta yang ada di lingkungan sekitar siswa dengan mengoptimalkan fungsi seluruh panca indera untuk mengidentifikasi permasalahan muncul dari fenomena faktual di lingkungan sekitar.

\section{Kearifan Lokal untuk Inovasi sumber belajar biologi}

Sumber belajar merupakan segala sesuatu yang dapat digunakan untuk kemudahan belajar. Sumber belajar berfungsi untuk memberikan fasiliatas kemudahan belajar bagi siswa sehingga efektifitas pembelajaran dapat tercapai. Sumber belajar terdiri dari enam komponen, yakni: Pesan, Orang, Bahan, Alat, Teknik, dan Lingkungan yang disingkat dengan kata POBATEL. Sumber belajar digolongkan menjadi sumber belajar by design dan by utilization. Sumber belajar by design adalah segala sesuatu yang dirancang dengan tujuan untuk memberikan kemudahan dan fasilitas untuk proses belajar siswa. Contohnya buku ajar, modul, alat peraga, media pembelajaran dan lain sebagainya. Sumber belajar by utilization adalah segala sesuatu yang dirancang bukan untuk tujuan pembelajaran namun dapat dimanfaatkan untuk belajar dan pembelajaran. Contohnya kebun binatang, taman nasional, pasar, bank, swalayan, suaka margasatwa, dan lain sebagainya. Kearifan lokal termasuk dalam sumber belajar by utilization, keberadaannya dapat dimanfaatkan sebagai sumber belajar karena dapat menanamkan konservasi nilai-nilai dan karakter yang terkandung dalam kearifan lokal tersebut dan sekaligus untuk pelestarian sumber daya alam.

Kearifan lokal termasuk di dalamnya potensi lokal merupakan salah satu fenomena yang berkembang di lingkungan sekitar masyarakat setempat untuk dapat dimanfaatkan sebagai sumber belajar biologi. Bentuk-bentuk kearifan lokal yang berpotensi sebagai sumber belajar biologi antara lain tumbuhan dan hewan endemik setempat, norma dan nilai setempat, adat istiadat, rumah adat, pakaian adat, lagu daerah, makanan daerah setempat dan lain sebagainya. Berbagai macam bentuk kearifan lokal tersebut dapat dimanfaatkan sebagai sumber belajar mengacu pada analisis Kompetensi Dasar yang termuat dalam Permendikbud Nomor 24 Tahun 2016 sesuai dengan kaidadah-kaidah yang mengatur implementasi Kurikulum 2013 dengan urutan langkah yang disajikan pada Gambar 1.

Kurikulum 2013 dikembangkan dengan mengacu pada pengusaan kompetensi abad 21 yang terdiri dari kemampuan kritis dan pemecahan masalah; kreatif dan inovatif; kolaboratif; dan komunikatif. Kemampuan-kemampuan tersebut dapat digali dari poetensi diri siswa melalui kegiatan pembelajaran yang memanfaatkan kearifan lokal di lingkungan sekitar 
sebagai sumber belajar. Pembelajaran biologi dengan mengintegrasikan kearifan lokal sebagai sumber belajar secara tidak langsung mampu melatihkan siswa untuk peduli dengan lingkungan sekitar, inisiasi untuk melakukan konservasi biologi dan konservasi nilai-nilai yang terkandung dalam kearifan lokal tersebut. Konservasi biologi dan konservasi nilai dapat dibiasakan melalui pembelajaran biologi di sekolah dengan memanfaatkan sumber belajar berupa kearifan lokal untuk menjadi karakter bangsa.

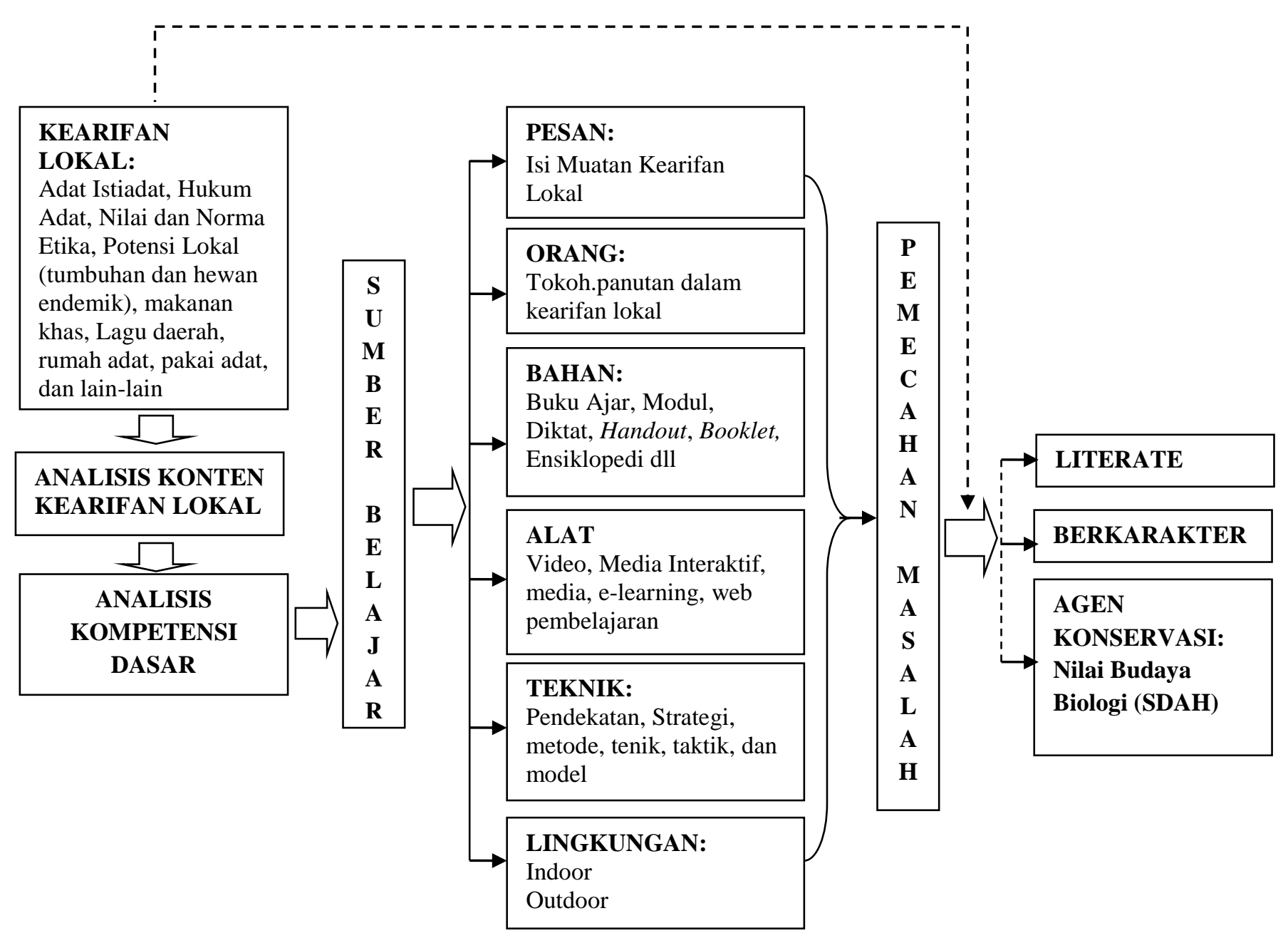

\section{Gambar 1. Model Intergrasi Kearifan Lokal dalam Inovasi Pembelajaran}

Kearifan lokal yang berada di lingkungan sekitar peserta didik dapat dimanfaatkan sebagai sumber belajar mereka. Pemanfaatannya sebagai sumber belajar mampu memberikan dampak positif bagi siswa untuk konservasi nilai-nilai budaya masyarakat setempat dengan cara meneladani nilai-nilai kearifan yang terkandung di dalamnya. Internalisasi kearifan lokal mampu menumbuhkan karakter siswa, karena pengembangan karakter membutuhkan kesadaran budaya dan kecerdasan budaya (Kartadinata, 2010). Kecerdasan budaya ditunjukkan dengan kesadaran mereka akan kearifan lokal yang ada di lingkungan mereka tinggal sehingga mereka sadar akan nilai-nilai budaya yang tinggi dan relevan dalam konteks kekinian (Said, 2013). 
Konservasi dapat dimaknai sebagai tindakan melestarikan sesuatu, khususnya pelestarian (preservation), pemulihan (protection), dan perlindungan (restoration) terhadap lingkungan alam, ekosistem alam, vegetasi dan satwa liar. Konservasi dapat diartikan sebagai etika penggunaan sumber daya untuk menjaga kesehatan dunia alam, perikanan, habitat, dan keanekaragaman hayati termasuk sumber daya tak terbarukan seperti logam, mineral dan bahan bakar fosil, dan konservasi energi, yang penting untuk melindungi dunia alam. Istilah konservasi identik dengan konservasi biologi atau konservasi alam secara fisik. Konservasi biologi adalah pengelolaan alam dan keanekaragaman hayati Bumi dengan tujuan melindungi spesies, habitat, dan ekosistem mereka dari tingkat kepunahan yang berlebihan dan erosi interaksi biotik (Sahney \& Benton, 2008; Soule, 1980; Soule, 1985). Konservasi biologi menerapkan penggabungan antara ilmu alam dan sosial untuk praktik manajemen sumber daya alam (Soule, 1986; Hunter, 1996; Meffe, 2006; Van Dyke, 2008).

Konservasi tidak saja ditujukan untuk alam dan lingkungannya secara fisik, namun konservasi juga dapat dilakukan untuk nilai-nilai dan etika yang berkembang di masyarakat, karena nilai dan etika merupakan dua elemen utama yang sangat diperlukan dalam konservasi (Van Dyke, 2008). Contohnya konservasi nilai-nilai dalam kearifan lokal ditunjukkan pada kearifan lokal masyarakat Kudus yang terkenal dengan Gusjigang (Bagus, Ngaji, dan Dagang). Gusjigang dapat dintegrasikan dalam proses pembelajaran biologi untuk menanamkan soft skill siswa di sekolah melalui materi dan metode pembelajaran yang dirancang guru dengan mengacu pada filosofi Gusjigang di sekolah dan juga kharisma dari panutan masyarakat Kudus yakni Sunan Kudus dan Sunan Muria (sosok yang dapat dicontoh) (Abid, 2017).

Efek lain yang dapat dimunculkan dengan memanfaatkan kearifan lokal sebagai sumber belajar adalah mampu membangun siswa yang literate jika kearifan lokal sebagai sumber belajar biologi di kelola dikelas secara baik dan tepat untuk pembelajaran siswa. Kearifan lokal berpotensi untuk menggali dan mengembangkan, melatih dan membiasakan keterampilan berpikir (habits of mind) melalui pembelajaran berbasis pemecahan masalah secara berkelompok. Pembelajaran yang demikian mampu melatihkan anak untuk melalukan analisis kritis terhadap kasus kearifan lokal yang ada untuk dilakukan pemecahan masalah secara kreatif dengan tetap memperhatikan hubungan personal sesama teman.

Kearifan lokal dapat dikelola dan dikemas untuk menstimulasi kegiatan membuat pertanyaan dan atau hipotesis dalam rangka melakukan investigasi untuk mengumpulkan data dan atau mencari solusi dari permasalahan yang bersumber dari kearifan lokal yang dilakukan siswa secara berkelompok. Kearifan lokal dapat dikemas dalam bentuk permasalahan untuk secara aktif dan analitik diindentifikasi masalah-masalah yang terkandung di dalamnya secara berkelompok.

Kegiatan pembelajaran yang didesain secara berkelompok untuk kegiatan pemecahan masalah yang bersumber pada kearifan lokal mampu melatihkan kemampuan berkolaboratif dan berkomunikatif. Serta meningkatkan berpikir analitik siswa. Berpikir analitik merupakan awal dari dimilikinya berpikir kritis oleh siswa. Berpikir kritis siswa merupakan saran untuk berpikir kreatif siswa. Berpikir kretaif siswa tidak akan dimiliki oleh siswa jika mereka tidak kritis. Namun demikian berpikir kreatif siswa dapat dilatihkan melalui kegiatan pembelajaran di sekolah dengan menggunakan model dan media pembelajaran yang tepat dengan bersumber pada kearifan lokal. 


\section{Metodologi Inovasi Sumber Belajar Biologi Berbasis Kearifan Lokal}

Kearifan lokal dapat dikemas dalam bentuk sumber belajar biologi melalui proses berpikir kritis dan kreatif guru untuk inovasi pembelajaran biologi. Gambar 1 menunjukkan langkah-langkah yang dapat dilakukan untuk mengintegrasikan kearifan lokal dalam bentuk sumber belajar siswa. Studi eksplorasi merupakan langkah yang tepat dalam usaha untuk menemukan karakteristik dari kearifan lokal yang dimilikinya. Studi eksplorasi yang dilakukan di daerah Banten ditemukan tiga kearifan lokal yang dapat digunakan sebagai sumber belajar biologi konservasi yakni kearifan Lembur (pengelolaan wilayah oleh masyarakat Banten), pemanfaatan tumbuhan untuk menunjang kehidupan sehari-hari, dan penanaman padi lokal. Ketiganya dapat digunakan sebagai sumber belajar konsep biodiversitas dengan sub konsep tingkat ekosistem, jenis, dan genetika (Leksono et al., 2015). Konservasi kearifan lokal masyarakat Kudus pada tamanan Parijoto sebagai upaya peran serta masyarakat khususnya guru untuk konservasi sumber daya alam melalui pembelajaran biologi (Mumpuni et al., 2016). Masyarakat memiliki kewajiban moral untuk memperbolehkan masyarakat tradisional menentukan daerah tinggalnya sendiri sesuai dengan sejarah dan budayanya (Jepson \& Canney, 2003).

Hasil kegiatan eksplorasi terhadap kearifan lokal setempat, untuk selanjutnya dapat dilakukan penyesuaian dengan analsis Kompetensi Dasar mata pelajaran biologi yang termuat di dalam Permendikbud Nomor 24 tahun 2016 tentang kompetensi inti dan kompetensi dasar pada tingkat jenjang pendidikan dasar dan menegah umum. Hasil penyesuaian dengan Kompetensi Dasar digunakan untuk memetakan materi dan menentukan inovasi sumber belajar yang akan digunakan, baik bersifat indoor dan ataupun outdoor. Langkah selengkapnya disajikan pada Gambar 1 .

Inovasi sumber belajar biologi dengan pengetahuan dasar kearifan lokal dapat dikemas dalam bentuk POBATEL, yakni pesan, orang, bahan, alat, teknik, dan lingkungan. Kearifan lokal dapat dikemas dalam bentuk desain pembelajaran (Mumpuni, 2013), dan bahan ajar (Leksono et al., 2015).

Metodologi inovasi kearifan lokal sebagai sumber belajar dapat dilakukan dengan menggunakan model penelitian Research and Development dengan model yang berbeda sesuai dengan karakteristik dari produk yang dihasilkan guru. Tidak ada satupun model pengembangan yang efektif untuk menghasilkan semua produk yang beragam. Penentuan model pengembangan disesuaikan dengan karakteristik produk yang dihasilkan.

Metodologi pengembangan produk media berbasis teknologi informasi dengan sumber utama kearifan lokal dalam wujud media interaktif dapat menggunakan model APPED (Analisis, Penelitian Awal, Perancangan, Evaluasi, dan Diseminasi) (Surjono, 2017); model Alessi Trollip (Planning, Design, Development) (Alessi Trollip, 2001); dan model LEE (needs assessment, front end analysis, design, development, Implementation, Evaluation) (Surjono, 2017). Metodologi pengembangan dengan produk desain pembelajaran (Rencana Pelaksanaan Pembelajaran/RPP) berbasis kearifan lokal dapat menggunakan model ADDIE (Analysis, Design, Development, Implementation, Evaluation) (Prawiradilaga, 2008) dan Borg and Gall (research and infoemation collecting, planning, develop preliminary from of product, premininary field testing, main product revision, main field testing, operational product revision, operational field testing, final product revision, dissemination and implementation) (Borg and Gall, 1983). 


\section{SIMPULAN}

Berdasarkan uraian yang telah dipaparkan, maka simpulan dari artikel ini adalah Kearifan Lokal berpotensi untuk inovasi sumber belajar biologi di sekolah guna membangun siswa yang litarate, berkarakter, dan sekaligus sebagai agen konservasi. Adapun metodologi untuk manifestasi produk sebagai sumber belajar biologi dengan pengetahuan utama kearifan lokal dapat menggunakan model penelitian pengembangan dengan pemilihan model disesuaikan dengan karakteristik produk yang dihasilkan.

\section{DAFTAR RUJUKAN}

Ayatrohaedi. 1986. Kepribadian Budaya Bangsa (Local Genius). Jakarta: Pustaka Jaya

Abid, Nuskhan. 2017. Integrating Soft Skill and GUSJIGANG Loval Value in The Learning Process. Elementary: Islamic Teacher Journal, 5(1): 169-190

Alessi, S.M, \& Trollip, S.R. 2001. Multimedia for Learning: Methods and Development. London: Allyn \& Bacon

Borg, W.R, \& Gall, M.D. 1983. Educational Research: An Introduction. New York: Longman.

Prawiradilaga, D.S. 2008. Prinsip Desain Pembelajaran. Jakarta: Kencana

Hunter, Malcolm L. 1996. Fundamentals of Conservation Biology. Oxford: Blackwell Science.

Jepson, P. \& Canney, S. 2003. Value-Led Conservation. Global Ecology and Biogeography: 12(4): 271-274

Kartadinata, S. 2010. Isu-Isu Pendidikan: Antara Cita-Cita dan Harapan. Bandung: UPI Press.

Leksono, S.M, Syachruroji, A., \& Marianingsih, P. 2015. Pengembangan bahan Ajar Biologi Konservasi Berbasis Etnopedagogi. Jurnal Kependidikan, 45 (2): 168-183

Mumpuni, KE., Susilo, H., dan Rohman, F. 2016. The Role of Society Toward Conservation. Prosiding Seminar Nasional XII Biologi, Sains, Lingkungan, dan Pembelajarannya. Surakarta: Pendidikan Biologi UNS

Mumpuni, K. E. 2013. Potensi Pendidikan Keunggulan Lokal Berbasis Karakter dalam Pembelajaran Biologi di Indonesia. Prosiding Seminar Nasional IX Biologi, Sains, Lingkungan dan Pembelajarannya dalam Upaya Peningkatan Daya Saing Bangsa. Surakarta: Pendidikan Biologi UNS

Meffe, Gary K.; Martha J. Groom. 2006. Principles of Conservation Biology (3rd ed.). Sunderland, Mass: Sinauer Associates. 
Said, Nur. 2013. Gusjigang dan Kesinambungan Budaya Sunan Kudus (relevansinya bagi pendidikan islam berbasis Lokal Genius. Jurnal Penelitian Islam Empirik, 6 (2):117138

Sartini, S. 2004. Menggali Kearifan Lokal Nusantara Sebuah Kajian Filsafati. Jurnal Filsafat, 14 (2): $111-120$

Sahney, S. \& Benton, M. J. 2008. "Recovery from The Most Profound Mass Extinction of All Time". Proceedings of the Royal Society, 275 (1636): 759-765

Soulé, Michael E.\& Wilcox, Bruce A. 1980. Conservation biology: an evolutionaryecological perspective. Sunderland, Mass: Sinauer Associates.

Soulé, Michael E. 1985. "What is Conservation Biology?". BioScience, 35 (11): 727-734.

Soule, Michael E. 1986. Conservation Biology: The Science of Scarcity and Diversity. Sunderland, Mass: Sinauer Associates.

Surjono, Herman Dwi. 2017. Multimedia Pembelajaran Interaktif: Konsep dan Pengembangan. Yogyakarta: UNY Press

Syamsiar, Cia. 2010. Bentuk-Bentuk Kearifan Lokal dalam Kehidupan Masyarakat Indonesia Sebagai Sumber Gagasan Berkarya Seni Rupa. Brikolase, 2(1): 1-6

Van Dyke, Fred (2008). Conservation biology: foundations, concepts, applications (2nd ed.). New York: Springer Science and Business Media. 